\title{
HOW COULD NATIONALIZATION OF RATE REGULATION BEST BE ACCOMPLISHED?
}

\section{By Martin S. Decker}

A nationalization of all railroads in the United States, including the regulation of rates and all practices affecting rates, was accomplished on December 28,1917, under proclamation by the President of the United States. All loyal citizens recognize the necessity of the act and admire without qualification the bravery of the action.

On that date the Interstate Commerce Commission and every state railroad commission temporarily ceased to exercise independent administrative or executive functions over the railroads of this country. They became subordinate investigating bodies, entirely subject to the superseding administrative and executive powers vested in the Director General of Railroads.

No order of any commission, federal or state, has today any binding force in law except with the consent of the Director General of Railroads; and any such order, if allowed to take effect and have application, may be suspended or nullified, with or without formal notice to the commission or any affected party, by action or authorization of the Director General. There is therefore no longer any real regulation of railroad rates by established tribunals throughout the United States.

Whatever rate regulating functions the Interstate Commerce Commission shall continue to exercise during the war will be in the main ancillary to governmental requirements, whether primarily arising because of wage increases or greater cost of railroad material, or because of the need for increased earnings from railroad operation to reach as far as practicable the measure of net earnings fixed by the government guarantee that they shall equal the average of net earnings for the past three years. It is clear of course that the state commissions will prefer to coöperate with the federal authority and not attempt unavailing antagonism to the provision of revenue deemed necessary for governmental railroad requirements by the Federal Railroad Director.

The public interest which the railroads of the country must now almost exclusively serve is that which pertains to the conduct and 
winning of the war. The public interest in the enforcement of common right to the movement freely by railroad of all freight and passenger traffic as commerce between localities, without wrongful prejudice to persons or places, and with all reasonable service rendered by the railroads at just and reasonable charges, which has been in peace times the great underlying purpose of the granted monopoly of railroad service to common carrier corporations, is today relegated by necessity to the extreme rear of the great procession of considerations which constitute problems for quick and right solution under the paramount needs of the nation at war.

It is mere sound to say that "we have rushed into a definite policy of government acquisition and operation of railroads for the commercial benefit of the people." We have done no such thing. The railroads have been taken over "by the war, of the war, for the war." This has been specifically stated by the President in his proclamation and in his following speech upon the same subject before the Congress.

All tests hitherto applied in railroad regulation have been submerged in the great ocean of war necessity. That is today the great test under which regulation must be applied in practice during the war. Mere public service, as distinguishable from the many forms of war service, can only be crumbs that fall from the table of major railroad war operations. Every railroad rate regulation order sought to be applied by any railroad commission during the war must properly be construed as bearing the prefix, "If the Director General of Railroads shall approve."

Think of it how we may, we come always to the great outstanding, unchangeable fact that the railroads of this country are operated today under requirements and prohibitions which correspond to martial law. No man or company can raise the sign "Business as Usual." That word "usual" has been changed to "possible." Men and corporations engaged in business of any description are now greatly concerned in securing transportation of their material and their agents upon any terms; they have little immediate concern with the price they have to pay for that transportation. It is not too much to say that regulation of railway rates, as we have commonly applied the term to fit normal business and normal commerce and to prevent discriminations and unjust rate exactions as affecting individuals, localities and kinds of traffic, 
has become, in this disrupting war time, almost a moot question. At any rate the subject does not present in these sacrificial days any large practical question for urgent immediate solution.

But this gives us a wonderful opportunity to realize our sins of the past and prepare for a sinless future with respect to railroad operations and railroad regulation. In making that preparation let us cast aside the idea of adopting for peace times the government ownership of railroads, or of continuing in peace times the government operation of railroads which has been found necessary solely for war purposes. We are now undertaking a forcible temporary government lease of United States railroads upon a stated net earnings basis - a lease which could not be effected in peace times, and the mere announcement of which as having been proclaimed, but by no means consented to in legal form by the railroad owners, carries no solution in and of itself and projects no title in the lessee beyond the necessary occupation of the properties for war purposes.

It is difficult to understand how enlightened intelligence can predict any cther result from ultra expensive war time operation by the goverminent than a large deficit of net earnings below the proposed net earnings rental basis. Nor can the experience of such war time operation supply a sound basis of computation upon which to take over the railroads for peace time operation by the government either as owner or lessee. Moreover, that great body of men who produce and buy and sell, who ship and reship the raw material and the manufactures which in myriad forms constitute the commerce of the country, will not be satisfied to trade the present legal responsibilities and obligations of common carrier corporations and the developed system of government regulation, both at common law and by statute, and as settled by the courts, for the arbitrary and practically unassailable rules, regulations and methods of government operation, theoretically controlled as they may be by general statutory provisions. For whatever may be said, under any system of government operation the elements which compose and control the government policy must have first consideration in all regulations, while under private ownership the railroad operations are required to be conducted always with first regard to the paramount public interest and rights of those whom the owners, in return for the public grant, have undertaken to serve. For example, there is no real federal common law. Shall we cast aside the multitude of 
rights now existing at common law as against railroads in the mere hope that the government will voluntarily observe them? Again, have we any ground for believing that a government operated railroad system in peace times will more readily respond without penalties to the rate or service requirements of a shipper or section of the country than a railroad corporation will with regulations applied under penalties for non-observance? We who submit, with or without protest, to the frequent poor service of the mails, which is only a single service, will answer "No" for the complicated services and rates involved in the carriage between thousands of localities of so many thousands of commodities and for the competitive interests of millions of shippers and consignees. And then we cannot disregard the blight which could be cast upon commercial interests as well as the whole public interest under the political influences that may so insidiously control not only the railway operations but also the elections through this control of the railways.

In preparing for the future we must still look forward to regulation, but it should be a new regulation. We must first realize that the old regulation of rates and practices affecting rates has failed. We see now as a nation of individuals what was perceived before by only a small class of individuals, that the revenues of the railways have not been sufficient, as a whole or for most roads individually, to pay the frightful increases of operating costs and yield sufficient in net earnings, after reasonable dividends, to permit the carrying of considerable balances each year to surplus for application to the cost of necessary future additions to lines, yards, terminals, and equipment or other contingent corporate purposes. Of course the result has been a limitation upon railway credit. Large discounts have been borne in the sale price of railway securities, and there has been restriction of all railway betterments and additions to those imperatively required at the time or in the time immediately to follow. The cost of money for the capital purposes of the railways has been extreme. The cost of floating short term notes to pay current debts or temporarily to meet maturing bond or note obligations has gone many points beyond the ordinary, sometimes termed legal, interest for loans. And the subsequent taking up of these notes, or directly of maturing bonds, by long term bonds has often required the issue of bonds largely in excess of the face value of the securities to be funded, so that many and often large excess issues, as well as 
discounts, have here again been involved. This has not meant arbitrary exactions by bankers. It has meant that the sale credit of the railways for their securities has been low as compared withi other offerings in the financial markets at the same times. The railway corporations have had to take on these extraordinary debt burdens and they represent in a real sense part of the cost of the property. The rates of the companies have not been sufficient in most cases to admit of the amortization of these extraordinary debt burdens and charges, to meet the current requirements of general debt charges and to give some proper return to the stockholders.

We have been blissfully oblivious to the facts that every railway company must constantly add to its facilities in order to serve economically the growing demands for service; that nevertheless every few years there comes a period of traffic recession, sometimes a long period, when many cars and engines are idle and much terminal space is empty; that in other years every facility and terminal of the railway are strained to the uttermost use, and are inadequate to supply the public with the service then demanded. A prudent manufacturer with part of his factory or equipment idle in recurring periods would in some way charge into his expenses or against his corporate income for the year the average profits lost through nonuse in the idle period of part of the factory or equipment. He would fix his prices to make up for his losses in dull periods to the fullest extent possible. No such prudent consideration has been taken into account in dealing with the railways.

We have failed to realize to the full that the railway business of the United States is the biggest business on earth; that its main purpose is to serve all otherbusiness; that it is in essential respects a part of all other business and must be conducted upon business principles if it is to be successful.

All rate regulations affecting the amount of general railway rates has proceeded upon the idea of necessary restriction and without assumption of the duty of railway protection. An exception is the prohibition of rebates and passes, although it was intended primarily to prevent discrimination against the individual railway patron and not for any declared purpose of protecting railway revenues. There were indeed many who claimed the prohibition was an attack upon the ability of the railways to get the greatest amount of revenue. Unquestionably that prohibition has cut off favoritism 
to selected shippers and industries, stabilized rates and fares, benefited all shippers as a class and all railways as a whole. No voice is now raised anywhere in favor of the old vicious rebate and pass system.

We now see plainly that the regulation of railway rates must extend to full protection of the railway business in order to insure the full rendering of railway service to the public at all times and under all conditions. If the Interstate Commerce Commission had been charged with the duty of requiring needed railway improvements fifteen years ago, together with the correlated function of efficiently regulating the capitalization of the railways, the discharge of those great duties would doubtless have brought to the Commission a responsibility for necessary protection that would have been strongly evident in recent years in determinations involving proposed increases of rates.

The President's great sentence that "The world must be made safe for democracy" went ringing through the nations and is still thrilling the hearts of men. His proclamation taking control of the railways that they might be made into a single system to serve efficiently and help save this democracy in war time has shown us our opportunity to let or make the railways save themselves for public service in the coming time of peace. The 262,000 miles of railway in this country now constitute a single system. Why not give the railways authority in law to operate as a single system in peace time so far as service needs may require? When the railways go back to their owners for operation let them be returned with statutory direction to continue operations as a single system in whatsoever ways economy consistent with good and sufficient public service shall demand. That would be real national regulation affecting rates as well as service. Let us erase the anti-trust laws from the statutes so far as they apply to railways, and repeal the anti-pooling section of the Interstate Commerce Act. Let the railways pool their earnings and their equipment as well. Let us even, in the public interest for real efficient service, direct them by statute to form and operate an over-lying equipment company, by which needed equipment can be had by any road sufficient to meet all traffic demands at all times, and can be returned when the need has passed. Not only let them, but, if good operation demands, make them, use yards and terminals and even tracks in common. Let us strike the shackles of restraint 
from all railway progress towards continuously efficient public service. In short, legalize railway combinations and railway pooling under adequate government control, which control should include service as well as rate regulation and the ordering of improvements to railroad property with supervision of all new capitalization. These old prohibitory anti-trust laws and anti-pooling laws were never necessary in railway regulation. They are now opposed to the sentiment of the time and they have always made the service of railways more costly to the people. Competition has no place in public service. The public can be well served only by the combined and directed energies and resources of all public servants having like duties to perform.

It is not generally remembered that a legalized pooling bill passed the House of Representatives about the year 1895, and failed of passage in the Senate because of the approaching close of the session. This was after passage of the Sherman Anti-Trust Law, which was enacted in 1890 . If the legalized pooling bill had become law, the anti-trust law would not have had further application to railroads. Twenty-three years ago we came near realizing in lawmaking that which it is apparent we must do in the present railroad crisis-recognize that these interlacing rail lines carrying the products of every market into every other market must be regarded in law as well as in fact as the American railroad system, to be operated in common service for the public use. Every railroad is a monopoly connected and used with every other railroad as a general railroad monopoly. What a paradox it is to say that such a necessary monopoly shall be subject to an anti-monopoly law! Today the government is itself a railroad monopoly because antimonopoly laws have made the railroads unable to cope with the great problem of efficient war time service.

The answer to the title of this paper is plain: mere regulation of railway rates of a repressive character has failed. With anti-trust laws and anti-pooling restrictions in force many large economies of operation have been impossible. Contracts between the carriers to enable use of the roads as a single system in the better and economical service of the public have been forbidden by law. Guarantees of traffic to weak roads have been unlawful. The stress of traffic upon strong roads has broken down their efficiency. It is not enough that the Interstate Commerce Commission shall permit 
increases in rates from time to time to some or all railroads. The nationalization of railway rate regulation should provide for orders by the Interstate Commerce Commission requiring increases, as well as decreases, of railroad rates. The whole viewpoint of our regulating traditions must change. The regulation of rates should be based upon a required high grade of service, not upon any grade of service. The regulating authority should have power to require that high grade of service and the property improvements requisite thereto. The regulating authority should have power to pass upon the issues of railroad securities and restrict such issues to railway capital purposes. There should be a Federal Railroad Loan Bureau, as there is today a Federal Farm Loan Bureau. As to railroads, the anti-trust and anti-pooling laws should be repealed and railroad combinations and railroad pooling, under supervision and restriction by the Interstate Commerce Commission, should be legalized. The investigating powers of the Interstate Commerce Commission should be constantly employed with a view to determining whether particular classes of railroads are charging rates high enough, under traffic conditions from time to time prevailing, to enable them to discharge at all times their charter obligations to render sufficient and good service to the public; and if not, the issuance of orders directing revision of rates upward, and the kinds of traffic to which they should apply, should follow. This would be nationalization of railway rate regulation for the national welfare, and in the light of recent events it is plainly the best way that it can be accomplished. The railway rate adjustments as between sections and localities and kinds of traffic would go on of course and be regulated as heretofore.

More and more the development of railway regulation has indicated that efficient regulation means full railway supervision, but that such supervision must be beneficent, and in no sense a response to attacks upon railway capital required for maintenance and continuous improvement of railway property to make it always adequate for the public needs. Such supervision must base its action upon facts, and whenever so based the people will sustain and commend it.

The railroad companies have been rightfully complaining of state regulation of railway capitalization, not because regulation of railway capitalization is oppressive or unjustified, but that, while recognizing its merits, large systems extending through several states 
ought not be subjected to separate regulation in this important respect by several independent governmental agencies; and that capitalization regulation of all interstate lines should be done by the single governmental authority which in other respects regulates interstate roads. The indictment so framed is sound, and state commissions themselves find no real objection to federal assumption of the duty of regulation, if a real and efficient system of capitalization regulation by the national government shall be established to apply to roads physically constructed across state lines.

The railroad complaint against state regulation of interstate rates stands upon quite another basis. There probably are constitutional difficulties in the way of complete assumption by federal legislation of the authority now exercised by the states over rates applying to transportation wholly within the states. The United States Supreme Court has consistently held that state legislation, whether fixing service hours for railway men, or requiring safety devices on railway cars, or prescribing maximum rates to apply within the state, and done directly by the legislature or by a commission created by the legislature, is void to the extent that it conflicts with regulation that has been lawfully applied by the federal government. If the new system of regulation suggested in this argument shall be fully provided, if the new rate regulation shall be based primarily upon required sufficient and good service to be shown first, or otherwise to be ordered, and if rates shall be adjusted first upon that prerequisite, with reserved resources provided by the roads always to meet extraordinary demands, it seems certain that such overshadowing regulation by the federal authority would speedily bring all state commissions into active coöperation with the new federal methods of regulation. The larger present need is to revise completely the national system of rate regulation and see what follows, rather than to waste energy now in arguing against state regulation of state rates which in some states is much more advanced along the lines here advocated than the present federal system of regulation. It is noted, moreover, that both the Interstate Commerce Commission and the state commissions have lately shown a most commendable coöperation in rate regulation matters, which ought to and would be fostered, and extended probably to all important matters, under the reforms in regulation here proposed.

Regulation of railways seems to be subject to important changes 
about every ten years. Beginning with 1887 , when the Act to Regulate Commerce became effective, we find that in 1897 the United States Supreme Court held that the Interstate Commerce Commission had no power to prescribe maximum rates; that in 1906, the Hepburn Act was passed giving the Commission that power and many other powers; and in 1917 came the war order taking over the railroads into government operation during the war. This would now seem to be the time to place federal regulation of rates upon a high service basis, since a high service basis is imperative if the tremendous commerce of the country which will require transportation after the war is to be well served.

The nationalization of railway rate regulation can best be accomplished by revision of the federal system of regulation to require the provision of continuous high efficiency of railway service; the fixing of rates to enable that high efficiency service always to be provided as a standard condition with all due allowances in rates for fair profits and necessary future improvements to railway property; the supervision of railway security issues; the marketing of railway bonds at fair prices; the compulsory expenditure of capital by the railways from time to time for property additions if not voluntarily undertaken; the legalization of railway contracts for combined and economical operations.

Successful regulation of rates must embrace all of these elements. If they should be incorporated into the system of national regulation, it will merely be the application of business principles to the world's greatest business. There will then be no complaint of over-regulation by carriers, although they will be more extensively regulated. There will then be little complaint by shippers against the amount of rates, because of satisfaction with the service and because with rates once adjusted under these conditions the operating economies with lowered cost of railroad loans will tend to cause reductions rather than successive increases in railway charges. The new system should be a constructive rate regulation, embracing at once all necessities of carriers in doing their work and the rights of the public in having that work well done. 